\title{
Pengembangan Kemasan Produk untuk Memperkuat Brand Stik Tempoyak Cap Cus di Jambi
}

\author{
Frangky Selamat ${ }^{1}$, Chairy $^{2}$, Hetty Karunia Tunjungsari ${ }^{3 *}$ \\ ${ }^{13}$ Jurusan Manajemen, Fakultas Ekonomi \& Bisnis, Universitas Tarumanagara, Jakarta \\ ${ }^{2}$ Fakultas Bisnis, Universitas President, Cikarang \\ Author E-mail: hetty@fe.untar.ac.id
}

\begin{abstract}
A B S T R A K
Krisis ekonomi yang dipicu oleh penyebaran virus SARS-Cov2 belum juga dapat dikendalikan. Kondisi ini telah menciptakan banyak masalah bagi pelaku UKM di Indonesia. Melemahnya daya beli konsumen dikuti dengan perubahan pola konsumsi masyarakat mendatangkan sejumlah masalah. Sektor kuliner menjadi salah satu yang terdampak berat. Usaha stik tempoyak yang merupakan hasil kreasi dari seorang ibu rumah tangga di Jambi yang ingin menciptakan oleh-oleh penganan ringan khas Jambi turut merasakan dampak tersebut. Berkurangnya jumlah kunjungan wisatawan ke Jambi dan pembatasan kegiatan masyarakat memaksa UKM ini untuk mengubah cara pemasaran. Cara luring dengan kemasan produk yang sederhana tidak dapat dipertahankan. Kegiatan PKM ini dilakukan untuk membantu UKM binaan agar dapat bertahan sekaligus melakukan inovasi pengembangan produk. Kemasan produk yang menarik dapat dimanfaatkan untuk aktivitas pemasaran daring, yang diperkirakan akan semakin intens pemanfaatannya sekalipun pandemi telah berakhir.
\end{abstract}

Kata Kunci: Kemasan Produk, UKM, Pemasaran.

\section{A B S T R A C T}

The economic crisis triggered by the spread of the SARS-Cov2 virus has yet to be controlled. This condition has created many problems for SME entrepreneurs in Indonesia. The weakening of consumer purchasing power followed by changes in public consumption patterns has created a number of problems. The culinary sector is one of the hardest hit. The tempoyak stick business, which was the creation of a housewife in Jambi who wanted to create a typical Jambi snack, also felt the impact. The reduced number of tourist visits to Jambi and restrictions on community activities forced these SMEs to change their marketing methods. The simple way of offline with product packaging is untenable. This community service activity is carried out to help fostered SMEs to survive while at the same time making product development innovations. Attractive product packaging can be used for online marketing activities, which are expected to be more intense even though the pandemic has ended.

Key word: Product Packaging, SME, Marketing.

Copyright $\odot 2021$ Authors. This is an open access article distributed under the Creative Commons Attribution License, which permits unrestricted use, distribution, and reproduction in any medium, provided the original work is properly cited. 


\section{PENDAHULUAN}

\section{Analisis Situasi}

Berawal dari pertanyaan,"Apa oleh-oleh khas Jambi?" Seorang ibu rumah tangga bernama bernama Thiur Maita Lubis menciptakan penganan ringan stik tempoyak. Tempoyak yang lazim dimakan dengan nasi, berubah wujud menjadi makanan ringan yang dapat disantap sembari santai.

Seperti pengakuan Thiur sebagaimana dikutip jambi-independent.co.id, omongan sang nenek mendorongnya membuat cara lain mengolah tempoyak. Jika Palembang memiliki oleh-oleh khas daerah yaitu pempek, maka Jambi pun mulai bisa berbangga dengan stik tempoyak.

Mobilitas karena dorongan ekonomi yang tinggi mendorong pergerakan manusia antar provinsi juga demikian kencang. Makin banyak orang dari luar daerah yang mengunjungi Jambi untuk berbagai keperluan. Pariwisata memang bukan andalan Jambi. Kekayaan alam seperti dari hasil perkebunan kelapa sawit dan karet menjadi andalan Jambi.

Di sektor pertambangan, sebagaimana ditulis Wikipedia, Jambi memiliki cadangan minyak bumi sebesar 1.270,96 juta m2, gas bumi sebesar 3.572,44 miliar m3 dan batu bara sebesar 18 juta ton. Cadangan minyak bumi berada di Kabupaten Tanjung Jabung Timur, dan Kabupaten Muaro Jambi. Sementara gas bumi sebagian besar terdapat di Struktur Muara Bulian, Kecamatan Muara Bulian, Kabupaten Batang Hari. Adapun batu bara cadangan terbesar terdapat di Kabupaten Bungo.

Oleh-oleh selalu identik dengan kunjungan wisatawan yang berbelanja buah tangan sebelum kembali ke daerah asalnya. Jambi memang belum menjadikan pariwisata sebagai sumber penghasilan utama daerah. Namun kunjungan dalam rangka bisnis pun kerap kali diakhiri dengan berbelanja oleh-oleh untuk keluarga dan teman. Peluang ini yang ditangkap oleh Ibu Thiur.
Stik Tempoyak Cap Cus, demikian nama yang diberikan awalnya hadir dalam sebuah pameran UMKM di sebuah hotel di Jambi. Dengan kemasan sederhana, stik tempoyak ini menyedot perhatian pengunjung pameran. Stik tempoyak pun dijual di pusat oleh-oleh di Jambi dan mulai mendapatkan tempat di hati wisatawan yang berkunjung ke Jambi. Kunjungan wisatawan ke Jambi memang tidak sepenuhnya untuk berwisata, tetapi lebih pada kunjungan dalam rangka dinas yang disertai dengan aktivitas wisata seperti berkunjung ke Jembatan Pedestrian dan Menara Gentala Arasy, serta tentu saja komplek candi Muaro Jambi, sebuah kompleks candi Hindu dan Budha terbesar di Indonesia.

Pandemi Covid-19 yang memaksa orang untuk mengurangi mobilitas berdampak terhadap kunjungan wisatawan di Jambi. Demikian pula dengan kunjungan dalam rangka dinas. Hal ini selanjutnya mempengaruhi penjualan Stik Tempoyak Cap Cus.

Pada awalnya penjualan stik tempoyak berfokus di pusat oleh-oleh, kini telah jauh merambah hingga menjangkau market place seperti Shopee dan Tokopedia. Pada situasi sekarang, distribusi melalui market place amat mendukung arus kas usaha yang mulai terganggu karena pandemi yang berkepanjangan dan belum dapat dipastikan kapan akan dapat dikendalikan.

Penjualan melalui daring banyak ditentukan oleh tampilan produk yang menarik, salah satunya adalah kemasan. Kemasan Stik Tempoyak Cap Cus seperti yang ditampilkan di salah satu market place ternama ditampilkan pada gambar 1 berikut ini:

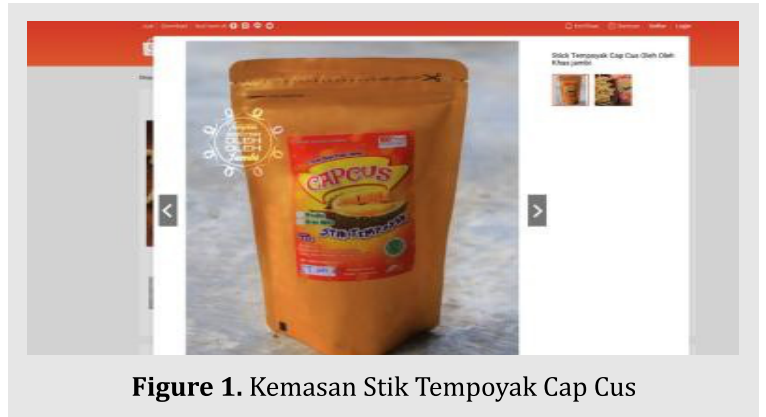


Kemasan stik tempoyak tampak cukup menarik tetapi masih kelihatan sederhana, yaitu menggunakan kemasan dengan clipper untuk memudahkan membuka dan menutup kemasan. Kemasan ini mudah ditemukan karena dijual di pasaran. Kemudian di satu sisi kemasan ditempel stiker merek Stik Tempoyak Cap Cus.

Pada perkembangan lainnya, kemasan Stik Tempoyak Cap Cus tampil dengan kemasan transparan, sehingga calon konsumen dapat melihat wujud stik tempoyak yang ditawarkan, seperti pada gambar 2 berikut ini.

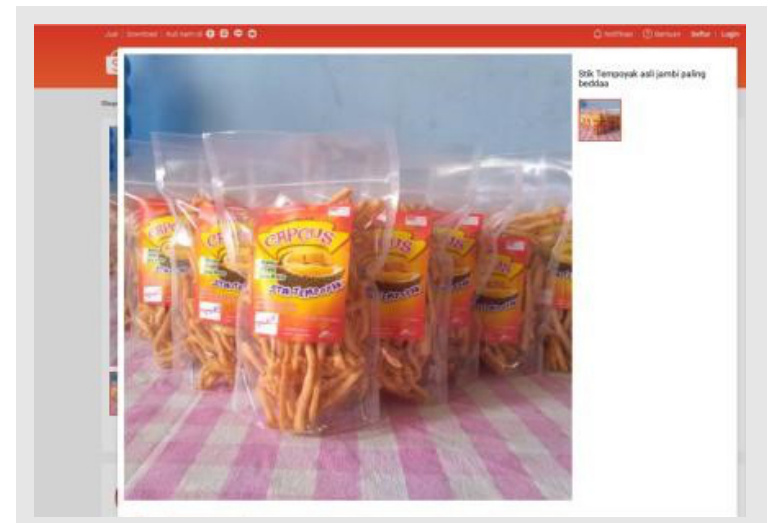

Figure 2. Kemasan Transparan Stik Tempoyak Cap Cus

Kedua tampilan kemasan cukup menarik walaupun masih berpotensi untuk dikembangkan lebih baik lagi.

Kotler dan Keller (2012) juga memandang pentingnya kemasan sebagai bagian dari alat pemasaran yang digunakan dalam rangka membangun brand equity. Menurut Kotler dan Keller (2012:346) pengemasan adalah seluruh aktivitas mendesain dan memproduksi tempat untuk memuat produk (container). Menurutnya terdapat tiga lapisan di dalam kemasan produk yaitu primary package, secondary package, dan shipping package. Selanjutnya menurut Kotler dan Keller, terdapat empat faktor yang mempengaruhi pemanfaatan pengemasan sebagai alat pemasaran, yaitu:

\section{Self-service}

Pengemasan yang efektif harus dapat menjalankan tugas penjual yaitu menarik perhatian, mendeskripsikan fitur produk, menciptakan kepercayaan konsumen dan membuat impresi keseluruhan yang bagus.

2. Consumer affluence

Konsumen mau membayar lebih untuk kenyamanan, penampilan, ketergantungan dan gengsi dari kemasan yang lebih baik.

3. Company and brand image

Kemasan berkontribusi atas pengakuan instan perusahaan atau brand. Di dalam toko, kemasan dapat menciptakan "efek papan reklame".

\section{Innovation opportunity}

Pengemasan yang unik dan inovatif dapat membawa keuntungan besar bagi konsumen dan produsen.

Perreault, Canon \& McCarthy (2011:205) mengemukakan bahwa kemasan yang bagus kadang memberikan efek promosi yang lebih kuat daripada periklanan. Selain itu kemasan yang bagus juga dapat menurunkan biaya distribusi, karena dapat mencegah barang mudah rusak dalam proses pengiriman.

Dengan demikian dapat disimpulkan bahwa kemasan memainkan fungsi yang sangat penting dalam pemasaran, tidak sekadar memuat produk, tapi juga menjalankan fungsi yang lain dan berdampak pada pembangunan brand $\mathrm{di}$ mata konsumen.

Kemasan Stik Tempoyak Cap Cus berpeluang untuk didesain ulang agar dapat memenuhi faktor seperti yang dikemukakan Kotler \& Keller, sehingga memungkinkan untuk meningkatkan penjualan serta membuka peluang pasar baru. Kemasan desain baru juga membuka kemungkinan untuk variasi stik tempoyak yang lebih variatif.

\section{Permasalahan Mitra}

Usaha yang dijalankan masih dapat ditingkatkan pengembangannya mengingat potensi yang dimiliki. Salah satu indikatornya adalah tingkat penjualan yang masih belum optimal. Potensi pasar yang ada masih dapat dikembangkan dan diperluas. Berdasarkan diskusi dengan pemilik usaha ini, diperlukan inovasi, agar usaha yang dijalankan dapat lebih berdaya saing. Salah satunya adalah memperbaiki desain kemasan 
sehingga makin menguatkan brand dan menawarkan variasi baru. Penggunaan media daring menuntut penyajian produk dalam kemasan yang lebih baik.

Pengemasan merupakan salah satu strategi yang dapat digunakan untuk mengkomunikasikan sebuah produk (Javed \& Javed, 2015). Konsumen biasanya selektif terhadap berbagai elemen visual. Berkomunikasi secara efektif adalah bagian penting dari desain instruksional, dan tampilan visual memainkan.

Kemasan yang dimiliki stik tempoyak Cap Cus masih dapat didesain lebih bagus karena tidak melibatkan desainer yang memiliki keahlian khusus dalam perancangannya, padahal kemasan adalah bagian dari produk dan satu kesatuan sebagai penawaran kepada konsumen.

Menurut Kotler dan Keller (2012:347) pengemasan harus mencapai sejumlah sasaran yaitu:

1. Mengidentifikasi brand.

2. Menyampaikan informasi yang deskriptif dan persuasif.

3. Memfasilitasi transportasi dan proteksi produk.

4. Membantu penyimpanan di rumah.

5. Membantu konsumsi produk.

Desain kemasan adalah bagian penting dari suatu produk, terutama untuk keberadaan produk baru di industri. Desain kemasan mencakup font, tata letak, dan warna yang digunakan pada produk. Skenario saat ini telah mengubah desain kemasan tidak hanya untuk melindungi barang dagangan dari kemungkinan bahaya tetapi juga untuk mendorong pembelian. Dengan kata lain, beberapa konsumen memilih produknya berdasarkan desain kemasan.

Wang (2012) menyebutkan bahwa tampilan kemasan mempengaruhi secara langsung persepsi konsumen terhadap kualitas produk makanan dan preferensi brand. Persepsi konsumen terhadap produk makanan secara langsung dan tidak langsung mempengaruhi preferensi konsumen terhadap brand. Dalam hal ini nilai produk juga menjadi faktor yang memediasi.

Lebih lanjut, Bezaz dan Kacha (2021) dalam sebuah eksperimen pada anak-anak memperlihatkan bahwa dimensi warna kemasan berdampak terhadap evaluasi anak-anak terhadap preferensi brand. Mereka menyimpulkan bahwa kemasan adalah alat pemasaran yang mempengaruhi evaluasi terhadap kemasan dan juga sikap konsumen, terutama pada titik penjualan (point of sale).

Kegiatan PKM untuk membantu pengembangan kemasan bagi UKM salah satunya dilakukan oleh Qonita dkk (2016) di daerah Sleman, Daerah Istimewa Yogyakarta, berupa pengembangan kemasan bagi UKM yang menghasilkan produk wingko babat. Wingko babat adalah makanan tradisional yang proses pembuatannya menggunakan kelapa parut.

Saat produk jadi dan dikemas untuk dipasarkan, seringkali muncul masalah kemasan berminyak karena rembes dari wingko babat. Hal ini tentu menjadikan produk kurang menarik karena terkesan tidak bersih. Kegiatan PKM tersebut kemudian menghasilkan desain kemasan yang lebih "marketable" karena tahan minyak sehingga minyak tidak rembes keluar kemasan.

Selamat dkk (2020) juga mengembangkan kemasan untuk produk nasi minyak instan yang diproduksi oleh UKM di Jambi. Kegiatan PKM ini membantu UKM yang memproduksi nasi minyak instan sebagai salah satu produk oleh-oleh Jambi. Kemasan yang awalnya mudah rusak karena menggunakan bahan baku karton tipis, melalui kegiatan PKM tersebut kemudian diganti menjadi kemasan berbahan baku alumunium foil dengan desain yang lebih kekinian. Dengan desain kemasan yang baru, konsumen memberikan penilaian yang lebih baik pada produk nasi minyak instan tersebut.

\section{Solusi}

Solusi yang ditawarkan untuk menyelesaikan 
permasalahan mitra dalam bidang pemasaran dan manajemen usaha meliputi hal-hal berikut ini:

1. Untuk menyelesaikan masalah mitra dalam bidang pengemasan produk difokuskan untuk peningkatan desain kemasan. Saat ini kemasan produk Stik Tempoyak Cap Cus masih dapat ditingkatkan lagi. Tim PKM akan membantu membuat desain kemasan agar kemasan produk Stik Tempoyak Cap Cus lebih menarik dan memiliki kesan kekinian.

2. Untuk menyelesaikan masalah mitra dalam bidang pemasaran, maka tim akan melakukan pendampingan terkait strategi pemasaran produk secara daring. Tim PKM akan menyusun strategi pemasaran melalui media sosial agar produk Stik Tempoyak Cap Cus dapat dipasarkan secara lebih luas.

Target yang ingin dicapai dari kegiatan ini adalah terciptanya kemasan produk Stik Tempoyak Cap Cus yang lebih menarik dan kekinian serta adanya strategi pemasaran melalui media sosial. Untuk mencapai target ini tim akan melibatkan mahasiswa dari FSRD prodi DKV yang membantu membuat desain kemasan untuk Stik Tempoyak Cap Cus.

\section{METODE PELAKSANAAN}

Metode pelaksanaan yang digunakan dalam kegiatan ini adalah sebagai berikut:

1. Pengumpulan data dan penyusunan proposal Dalam menyusun proposal kegiatan PKM, tim melakukan wawancara dengan pemilik dan pendiri usaha Stik Tempoyak Cap Cus untuk mengidentifikasi masalah mitra. Setelah diketahui permasalahan yang dihadapi mitra, tim PKM melakukan studi literatur untuk mencari solusi yang tepat bagi permasalahan mitra.

2. Pelaksanaan

Pelaksanaan kegiatan PKM adalah dengan melakukan konsultasi secara online dengan menggunakan media Zoom meeting dan diskusi di pesan WhatsApp.

3. Penyusunan dan penyerahan laporan

Kegiatan ini dilaksanakan untuk Stik Tempoyak Cap Cus. Tujuan kegiatan PKM adalah untuk meningkatkan aktivitas pemasaran melalui pengembangan kemasan. Setelah kegiatan ini dilaksanakan maka tim PKM akan menyusun laporan dan menyusun draft publikasi terkait dengan kegiatan ini. Hasil dari kegiatan ini nantinya akan dijadikan dasar untuk menyusun rencana kegiatan lanjutan.

\section{HASIL DAN PEMBAHASAN}

Dibandingkan dengan UKM lain di Provinsi Jambi yang bergerak di kuliner, kinerja Stik Tempoyak Cap Cus, relatif lebih baik. Pemiliknya, Ibu Thiur Maita Lubis, memiliki pengetahuan, pengalaman dan kemauan yang cukup mumpuni untuk menjalankan bisnis kuliner stik tempoyak, sehingga masih tetap eksis hingga kini.

Ketika masih dijual dalam kemasan yang sederhana, Ibu Thiur secara aktif memasarkan stik tempoyak ke berbagai tempat di Jambi, terutama yang ditujukan bagi para wisatawan nusantara yang berkunjung. Dia juga aktif mengikuti berbagai pameran UKM Jambi yang saat itu sering diselenggarakan.

Awalnya memang tidak mudah bagi orang untuk menerima tempoyak dibuat dalam versi stik atau kudapan ringan karena tempoyak biasa dimakan sebagai lauk pauk. Namun dengan kemauan yang kuat untuk memperkenalkan stik tempoyak sebagai oleh-oleh khas Jambi kepada wisatawan yang datang, usaha itu telah menampakkan hasil. Popularitas stik tempoyak yang diberi brand Stik Tempoyak Cap Cus, mulai terbangun. Sejumlah wisatawan yang mengunjungi Jambi mulai menjadikan Stik Tempoyak Cap Cus sebagai "bawaan" wajib dari Jambi.

Sayang kondisi itu tidak bertahan lama karena pandemi melanda Indonesia sejak Maret 2020. Pergerakan orang dibatasi termasuk kunjungan antar provinsi yang akhirnya juga menekan kunjungan wisatawan ke Jambi. Penjualan stik tempoyak Cap Cus pun menurun drastis. Tidak banyak orang yang mengunjungi pusat oleh-oleh. Padahal sebagian besar penjualan stik tempoyak 
berasal dari pusat oleh-oleh. Memang, stik tempoyak ini juga dijual di market place seperti Shopee dan Tokopedia, namun penjualan melalui market place berbeda dengan di pusat oleh-oleh. Di pusat oleh-oleh wisatawan dengan mudah melihat secara langsungstik tempoyak yang dimaksud, dan percaya bahwa brand Cap Cus memiliki kualitas yang bagus. Berbeda dengan market place. Orang yang hendak membeli semestinya telah memiliki pengetahuan dan pengalaman terhadap stik tempoyak Cap Cus. Jika tidak, kecil kemungkinan terjadi transaksi.

Penjualan melalui market place telah membuka pasar baru bagi Ibu Thiur. Tidak cuma bagi orang yang telah mengenal Stik Tempoyak Cap Cus tetapi juga bagi orang yang ingin mencicipi kudapan ringan khas Jambi. Di sini peran pengemasan produk menjadi begitu penting.

Awalnya Stik Tempoyak Cap Cus dikemas begitu sederhana dalam dua versi yaitu kemasan plastik tertutup dan kemasan transparan. Tidak ada masalah berarti dalam penjualan secara offline di pusat oleh-oleh di Jambi. Lain cerita dengan penjualan secara online, karena tampilan di layar gadget, laptop atau komputer, terlihat sederhana dan kurang "eye catching". Kemasan lama tidak buruk tetapi menjadi kurang "menarik perhatian" ketika tersaji secara online, tidak melihat secara langsung. Oleh karenanya tim Pengabdian kepada Masyarakat (PKM) dibantu oleh mahasiswa FSRD Untar mencoba membantu untuk mendesain ulang kemasan Stik Tempoyak Cap Cus. Selain dengan tampilan yang lebih menarik, kemasan baru juga diharapkan dapat memperkuat brand Cap Cus.

Setelah melalui diskusi dengan Ibu Thiur mengenai kemasan yang sesuai untuk stik tempoyak Cap Cus, tim PKM mencoba mendesain kemasan baru seperti yang disajikan pada gambar 3 berikut ini:

Pada gambar 3, tampilan depan kemasan tampak lebih "segar" dengan pemilihan warna kuning sehingga lebih menarik perhatian konsumen. Pada bagian atas tampilan depan kemasan terdapat tiga aspek penting yaitu logo sertifikasi halal MUI, pernyataan "oleh-oleh khas Jambi" dan logo "100\% Indonesia". Di tengah-tengah terdapat gambar siluet Ibu Thiur dengan tulisan "Cap Cus". Ini untuk mengingatkan bahwa pemilik usaha ini adalah seorang wanita.

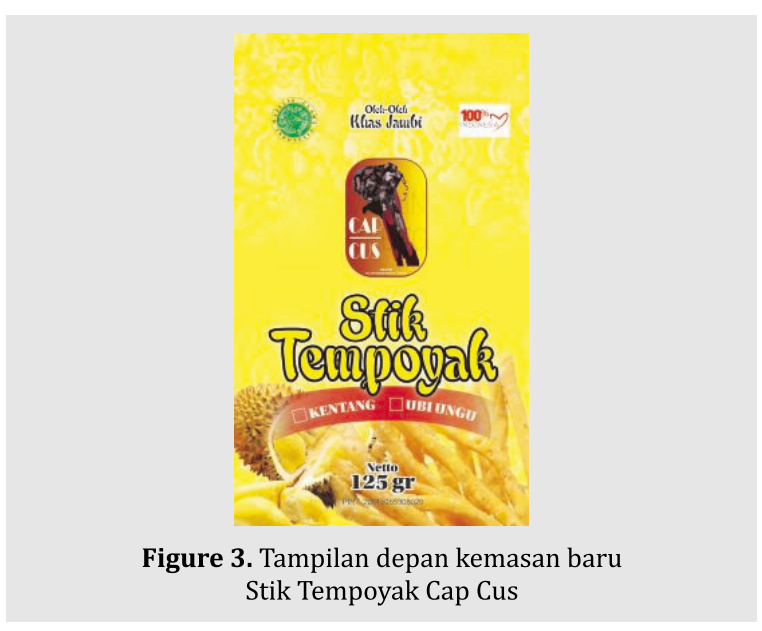

Tulisan "Stik Tempoyak" menjadi sajian utama karena telah dikenal dengan oleh banyak orang, dengan menambahkan keterangan rasa, kentang atau ubi ungu, selain tentu saja keterangan berat bersih (netto).

Sementara untuk bagian belakang kemasan baru disajikan pada gambar 4 berikut ini.

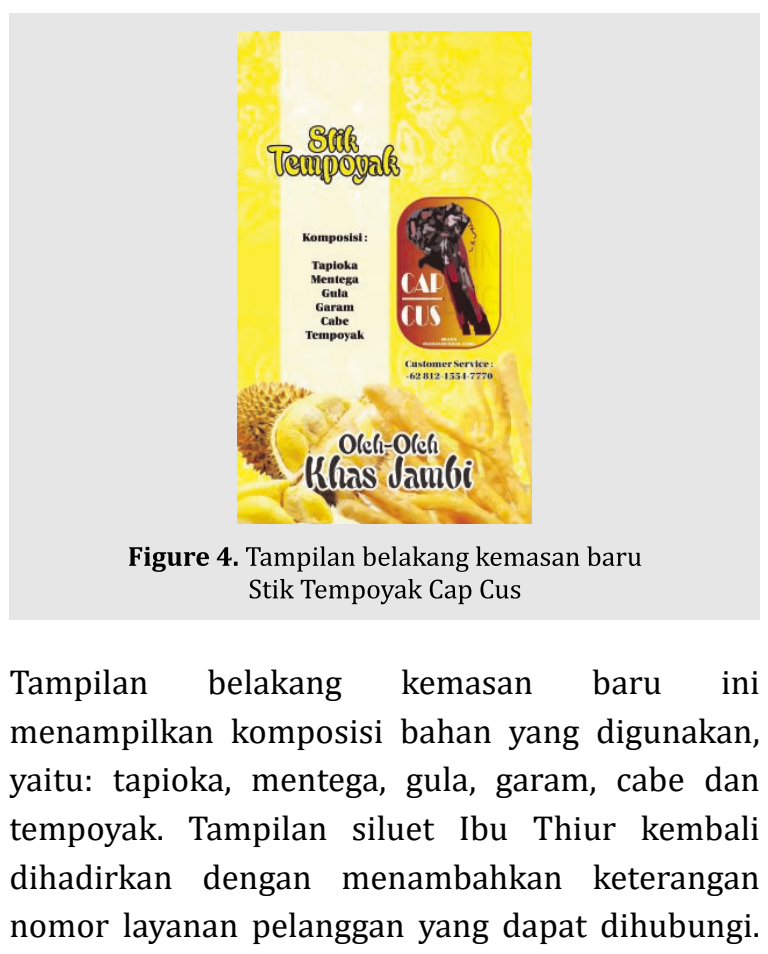


Tentu ini langkah maju bagi Ibu Thiur karena telah menempatkan pelanggannya sebagai bagian penting dari keberadaan Stik Tempoyak Cap Cus.

Kemasan baru ini dengan tampilan yang segar diharapkan dapat mendorong penjualan stik tempoyak Cap Cus, baik online maupun offline, lebih optimal lagi. Fungsi-fungsi kemasan seperti yang dikemukakan oleh Kotler dan Keller (2012:347), yaitu mengidentifikasi brand menyampaikan informasi deskriptif dan persuasif, memfasilitasi transportasi dan proteksi produk, membantu penyimpanan di rumah, dan membantu konsumsi produk, diharapkan dapat terpenuhi. Hal ini juga sejalan seperti yang dikemukakan oleh Javed \& Javed (2015) bahwa pengemasan produk adalah bagian dari cara mengomunikasikan produk.

Implikasi dari kegiatan PKM ini dapat dilihat dari sudut pandang teoretis maupun praktis. Secara teoretis, luaran dari kegiatan PKM ini dapat memperluas publikasi pada topik pengembangan potensi pemasaran UKM melalui pengembangan kemasan produk yang tepat. Adapun secara praktis, luaran kegiatan PKM ini memberikan manfaat langsung pada mitra melalui desain kemasan yang dihasilkan. Kemasan baru dengan tampilan yang lebih menarik dapat membantu meningkatkan potensi pemasaran produk UKM.

\section{KESIMPULAN}

Berdasarkan kegiatan pengabdian kepada masyarakat yang telah dilakukan dalam rangka pengembangan kemasan Stik Tempoyak Cap Cus di Jambi maka dapat diambil kesimpulan sebagai berikut:
1. Pengemasan produk Stik Tempoyak Cap Cus merupakan bagian dari strategi komunikasi kepada konsumen yang menyangkut informasi deskriptif dan persuasif tentang produk.

2. Pengemasan produk yang baik adalah bagian dari upaya membangun brand Stik Tempoyak Cap Cus, sebagai oleh-oleh khas Jambi.

3. Kemasan yang baru tersaji lebih menarik dibandingkan kemasan lama sehingga penjualan stik tempoyak, baik secara offline dan online diharapkan dapat mencapai tingkat yang optimal.

Kegiatan PKM serupa sebaiknya dapat dilakukan lebih masif di masa mendatang sebagai bentuk kontribusi bidang keilmuan akademisi bagi masyarakat secara praktis dan implementatif. Dosen dan mahasiswa dapat menerapkan keahlian yang dimilikinya untuk dapat membantu meningkatkan kualitas produk UKM. Di sisi akademisi, produk yang dihasilkan merupakan Teknologi Tepat Guna yang dapat dimanfaatkan oleh masyarakat. Adapun di sisi UKM, mereka mendapatkan manfaat transfer keilmuan dalam bentuk peningkatan kualitas produk (melalui desain kemasan yang lebih menjual).

\section{Ucapan Terima Kasih}

Terima kasih kepada Lembaga Penilitian dan Pengabdian Kepada Masyarakat (LPKM) Universitas Tarumanagara atas dukungan material dan nonmaterial yang diberikan, Ibu Thiur Maita Lubis selaku pemilik Stik Tempoyak Cap Cus, Jambi, dan asisten pelaksana Ivana Octavia dari FSRD Untar.

\section{DAFTAR PUSTAKA}

Bezaz, N., \& Kacha, M. (2021). An experimental study of the effect of packaging colour on children's evaluation of packaging and attitude towards the brand. International Journal of Retail \& Distribution Management, Emerald Publishing Limited, 0959-0552.

Javed, S. A., \& Javed, S. (2015). The impact of product's packaging color on customers buying preferences under time pressure. Marketing and Branding Research, 2(1), 4. 
Kotler, P \& Keller, K.L. (2012). Marketing Management, $14^{\text {th }}$ edition, Upper Saddle River, New Jersey: Pearson.

Perreault W.D, Cannon J.P., McCarthy E.J. (2011). Essentials of Marketing, A Marketing Planning Strategy Approach, $13^{\text {th }}$ edition, McGraw-Hill.

Qonita, Rr. A., Parnanto, N.H.R., Harisudin, M. (2016). Pengembangan kemasan yang marketable pada UKM Sofi dan UKM Wida di Desa Sendangagung Kecamatan Minggir Kabupaten Sleman. Prosiding Seminar Nasional \& Call For Paper DIES NATALIS XXXIII Universitas Islam Batik Surakarta ISBN: 9789791230353.

Selamat, F, Tunjungsari, H.K., Mulyawan, B., Chairy, C. (2020). Pengembangan Kemasan Produk dalam Rangka Membangun Merek Nasi Minyak Instan di Jambi. Journal of Journal of Sustainable Community Development, Vol. 2 (2), pp. 101-109

Wang, E.S.T.(2013). The influence of visual packaging design on perceived food product quality, value and brand preference. International Journal of Retail \& Distribution Management, Vol 41, No. 10, pp. 805-816 